\title{
Call for Associate Editors
}

Federal Governance a graduate journal Theory and Politics of Federalism and Multi Level Governance

Founded at the Institute For Intergovernmental Relations at Queen's University

Sponsored by the Forum of Federations

Federal Governance invites nominations and applications for up to four associate editors.

Deadline for applications and nominations is September 27th, 2013. Please send nominations, applications and inquiries to editor@federalgovernance.ca

\section{Applicants and Nominees should:}

- Be a graduate student

- Send a curriculum vitae of the candidate

- Have a good knowledge of federalism and multi level governance

- State a reference person

- Should have enough time capacities and resources to attend editorial skype meetings on a monthly basis

The successful candidate(s) will become full member(s) of the editorial board and contribute to the entire publishing process of the graduate journal. Tasks include for example maintaining and enlarging a network of peers and authors or implementing the journals formal requirements to submissions.

For more information about Federal Governance, please visit the website at: http://library.queensu.ca/ojs/index.php/fedgov 